\title{
Chapter 6 \\ Legitimacies in Peril: Towards \\ a Comparative History of Elites and State in Nineteenth and Twentieth Century \\ France and Western Europe
}

\author{
Christophe Charle
}

Since the French Revolution, the country's elites, ${ }^{1}$ especially those connected to the state, have seen their legitimacy challenged on a regular basis. From a historiographical standpoint, the study of elites has been characterized by two main approaches. The first has emphasized the political dimension and measured the effects on an individual level, of the many regime changes in the nineteenth and twentieth centuries. Instead of only examining leading players, historians have sought to establish from which social groups the new ruling teams came, to account for the struggles over power between competing fractions. The second, more rewarding approach has drawn on the sociology of state elites to identify the mechanisms of reproduction and transformation of the dominant classes, of which political elites only form the most visible fraction. This approach comes closer to a social history of the state, as these elites serve as models to legitimize successive regimes. However, both approaches neglect collective social traits which would be useful to consider to take better stock of the changes and continuities they seek to evidence. The comparative social study of state elites in these two centuries must no longer only address the two questions: 'who governs?' and 'how did they get to the top?',

Translation from French by Jean-Yves Bart

\begin{abstract}
${ }^{1}$ The term "elites" comes with certain limitations, due to the Paretian legacy and its vague empirical usage in some studies. Yet it also has two benefits: first, the word is a practical, abstract encompassing of the variety of ruling or dominant groups that have succeeded each other in France for two centuries, and whose historically dated names have changed with the regimes; second, the plural form reflects two marked features of French dominant groups that I seek to illuminate in this chapter - namely, the plurality of competing groups in the field of power and their constantly challenged legitimacy.
\end{abstract}

\author{
C. Charle $(\bowtie)$ \\ University of Paris I Panthéon-Sorbonne, Paris, France \\ Institut d'histoire moderne et contemporaine, Paris, France \\ e-mail: christophe.charle@ens.fr
}


but also, and crucially, investigate what, in the sociology of power elites, explains the characteristics of specific regimes, their relations with the dominant society and the blocking mechanisms that resurface periodically and deepen political crises in France, more so than in other European countries, even in the absence of outside historical accidents. Why do these elites, who are meant to embody the state's supreme legitimacy, keep being rejected by significant, if not majority, fractions of opinion, forcing changes in the rules of the game?

The most frequently proposed explanations for this are based on tautologies revolving around catchwords such as "sick man of Europe", "crisis of elites", "oligarchic drift", "microcosm", etc. To avoid these pitfalls, we need to link the two ends of the chain. The behaviours and choices of successive elites indeed depend equally on their social characteristics and on the extent of their flexibility regarding the demands, or resistances, of their supposed or actual mandataries, and the senior civil servants that ensure continuity in politics.

\section{The Napoleonic Model and the Prussian Model}

Since Taine, it has been commonplace practice in the study of elites to pinpoint the Napoleonian regime as the founding moment of what Pierre Bourdieu later called "state nobility". However, this bird's eye view actually condenses the chronology by antedating a system of selection of administrative elites that was gradually formalized over the course of the nineteenth century (Charle 1980). Until the late nineteenth century, most corps were spared open competition. Land ownership and the family's social capital were just as crucial in accessing administrative or political state functions as the pyramid of concours [competitive exams], which was developed little by little up to and including the prestigious national school of administration (ENA). To understand the largely unfulfilled impetus of the Napoleonic system, the paradoxical phrase employed by Gert Schubring in reference to the Humboldtian reform of universities, "modernization against modernity" (Schubring 1991), comes in handy. In Prussia, the Napoleonic system managed to survive just barely until 1918, whereas in France it endured only between 1802 and 1814 and from 1852 to 1870. The comparison of the two systems sheds light on the failure of the first model. Prussia's reformist leaders sought to combine modernizing reforms, inspired by revolutionary principles, with the strengthening of a state structure resting on the traditional elites. The latter went on partially providing the new executives needed by this Obrigkeitstaat (the state steered from above; Koselleck 1981). Conversely, in the Bonapartist regimes, the old and new elites and the two types of state elites did not merge as durably as in the Prussian nobility - not for lack of political perseverance. How are we to explain this recurring failure? Highlighting the ruler's isolation and the strength of the military would be treating the effect as the cause. In fact, the Napoleonic system did enjoy fairly broad support in French opinion both in 1814-1815 and in 1870, even in the working classes; however, it was left to its own devices by its own elites. 
The Napoleonic state sought to reconcile the classes but ended up doing so mainly to the benefit of the state elite, who were favoured in the process of sharing the spoils - both Bonapartist states generously distributed advantages and honours. This effort was in fact strictly impossible outside of periods of exceptional prosperity (most of the Second Empire) or failing the artificial assistance of the continental blockade and the pillaging of the territories conquered under the First Empire. Hence, the crises of the regimes that emulated this model in France and elsewhere regularly coincided with the end of this prosperity consensus, following an economic and/or social crisis. In 1814 and in 1870, the military and political crises that led to these regimes being toppled were accelerated by underlying conflicts resulting from the downturn. Likewise, the inability of the German Reich, which was dominated by Prussia, to ensure the civilian population's food supply during the 1914 war, and to balance the interests of the different groups within the wartime economy, triggered the collapse of the Prussian monarchy in 1918, even before the military defeat came (Winter 1989; Bessel 1993; Vincent 2006). The credibility of the state elites who were connected to this state model was deeply damaged, and the abuses that characterized their management of state affairs were not as well tolerated as previously by the groups who were denied access to state privileges.

This succession of events, observed in other regime changes, does not fully account for the paradoxical frailty of these "strong" regimes with enlightened elites, who wound up helpless in the face of historical contingency. There was, indeed, a second weakness in the state elites of the Napoleonic regimes, which was specific to France: it lay in their inability to establish a lasting balance between central and local power. The complete subordination of local power to central power emerged during the Consulate period out of the fight against civil war in the provinces and the anarchy of the Directory; during the Second Empire, it was also legitimized by the unexpected provincial resistance to the coup d'état of 2 December 1851 (Agulhon 2002).

This initial imbalance between central and local power entailed two shortcomings: first, the relative ineffectiveness of the centre/periphery relays who reported on the rapid loss of trust in the regime (as evidenced by the early embrace of the monarchy restored in 1814 in peripheral regions and the fairly smooth replacement of Napoleon III's prefects by Gambetta's in September 1870). Secondly, the subordination of the province indirectly favoured the emergence of a counter-elite with a local base, who drew on anti-centralism to rally the dissatisfied populations and denounce the official state elite. Instead of dividing and distributing political legitimacy, the Napoleonic state not only concentrated it in the hands of a select few (a group that tended to dwindle rather than expand, since nepotism increases as leading teams grow older), but also and most importantly, it gave the ultimate authority to those who had the fewest connections with the population they were meant to govern. The rare elected representatives were in a subordinate position and themselves rather handpicked than elected under the system of the "lists of notables" in the First Empire and the official candidacies of the Second Empire. The deputies in the 1852 legislature and the Bonapartist parliamentarians of the Third Republic came from the same privileged circles, even as their political movement claimed to 
represent the nation at large. ${ }^{2}$ This principle of political and administrative exclusion tended to swell the ranks of the categories who rejected this top-down consensus. The most helpless social groups were ultimately those who remained the most faithful or nostalgic of the formal security that State afforded them (such as the peasants and the military men), whereas their opponents tended to come from professional groups that enjoyed some social autonomy and had social networks that a less centralized regime would enable them to convert into social and political capital (as in the "capacities" of censitary regimes and Gambetta's "new social strata") (Nord 1995).

Conversely, it appears that the Prussian model was able to last thanks to three factors that were preserved throughout the nineteenth century. First, unlike the Napoleonic nobility, the Prussian nobility retained its political unity in the face of all the crises that threatened its privileges: it succeeded, for instance, in blocking the several land law reforms that attempted to remove the trusts who ensured that noble estates would be passed on from generation to generation. Economically, it also made the most of the agrarian reforms, by buying back feudal rights and in the process increasing its share of land ownership. By the late 1870s, the nobility still owned 31.9\% of the Prussian territory, i.e., 5.7 million hectares; thanks to the trusts, it had insured between a quarter and a third of its estates against the risk of alienation. This unity also related to a persistent social exclusivism that contrasted with the diversity of alliances forged by the Napoleonic nobility as well as the old nobility (Grange 1995, 2016; Bravard 2013). Lastly, for the noble cadets who had been denied land inheritance by a trust or for the aristocratic families who had been impoverished by recurrent agricultural crises, preferential access to central and local administrative functions and to the officers' corps ensured their survival in symbiosis with the state and made them a lasting political counterweight to the liberal and bourgeois groups, among whom some had been incorporated into the dominant group through a selective ennoblement policy. This lingering hegemony has been extensively debated among German historians. The simplistic schemes of the "betrayal" or "feudalization" of the bourgeoisie are now widely rejected (Kaelble 1996, pp. 251-253 and 258-259). In fact, recent studies evidence an enduring differentiation between the noble world and the bourgeois world; snobbery, on the other hand, was typical in French and English elites, where social connections between the aristocracy and the grande bourgeoisie were far more common. Acceptance of the noble Prussian hegemony in the new Reich might also have been partly the result of the spatial multipolarity of the German space. Decentralization and the federal system allowed local bourgeoisies, especially in the bigger cities, to yield a political influence that was equivalent, if not greater than, that held by their French counterparts in the municipal regime, which in their centralized state remained under prefectural supervision. Insofar as the federal state reconciled the

\footnotetext{
${ }^{2}$ See Eric Anceau (2000), especially the table on p. 298: the best represented professional group was that of businessmen and wealthy landowners (between 59\% and 51\% depending on the term), followed by senior civil servants (between $23.5 \%$ and $15 \%$ ); the middle class and liberal professions made up the rest of the membership (between $28 \%$ and $23 \%$ ).
} 
interests of the different groups through the choice of protectionism, which protected both the nascent industries and the increasingly less profitable agricultural productions in the East from competition, why would the German bourgeoisies have laid claim to the symbolic appropriation of central power, which did not bring the same benefits as in France? It would in fact be at the level of municipal power in big cities that the crisis and the contradictions of this state and its elites, suited to an agrarian society and small towns, ignited between 1900 and 1918 .

\section{An Ill-Fated Effort to Emulate the English Model}

While Prussia was influenced by the Napoleonic model, French state elites sought to draw on the English model. The system of French notability was roughly similar to the domination of the gentry over the English state. Eighteenth century French liberals were genuinely fascinated with that class of landowners, because it fulfilled a large part of the country's administrative and political functions independent of the central state, which was reduced to a bare minimum (Taine 1872). The French notables were also impressed by the fact that the gentry's power was, for the most part, acknowledged in the dominated groups and by the new bourgeois classes of industry and trade (Hobsbawm 1996). The attraction was palpable among the theoreticians of French parliamentarism (including Guizot) and also transpired in the social behaviour of the nobility and of the notables, recorded in monographs on regions where the latter had the most power (Denis 1977; Guillemin 1982; Vigreux 1987; Pourcher 1987; Brelot 1992). The ideal notable drew on local networks to access various levels of power; his chance of accessing the upper level was proportionate to the volume and diversity of accumulated capital. The social pyramid and the political pyramid were thus virtually one and the same, with the exception of a few social climbers and individuals whose intellectual capital, despite the system's general philosophy, served as the foundation of their political success.

However, to establish their social and political legitimacy, the English titled aristocracy and gentry drew on a property capital that was far more considerable than that of French notables, as there had been no revolution in their country. By 1873 , 38,000 families owned 27 million out of a total of 34 million acres of land in England and Wales, and the 2000 richest families alone held a third of all agricultural land (Whetham 1978, p. 52). These huge amounts of property capital allowed them to retain economic and social control of far bigger chunks of the country, and the lasting specificities of the electoral system and the geographical distribution of seats at the House of Commons made their political positions unassailable.

Meanwhile, the country's administrative apparatus remained modest. The French liberals' denunciation of the excessive size of the civil service actually drew on comparison with the English case (Thuillier 1980, 1983). English notables fulfilled a number of functions in an unpaid, voluntary capacity, which in France would usually have been entrusted to civil servants without capitals of their own or strong local connections. The existence of a system of devolution of property and the 
education of this class, which was exempted from common law (with primogeniture and public schools), ensured the lasting identity and the economic and cultural reproduction of this group and its role within the state.

In French, neither the old nobility, nor, with all the more reason, the notables (big or small) ever enjoyed the same perks as their English counterparts. Not only did they have less property capital, but the dividing up of land threatened them at each generation; meanwhile, profound religious and cultural divides, reflected by the dualistic (Catholic and state) education system, hindered the transmission of their social ideal and reproduced the division of political options. The notables also came up against competition from professional elites in connection with the far more anonymous and deterritorialized state, derived from the Napoleonic system, a fraction of which did not come from their own ranks, whereas in Great Britain higher education was almost exclusively in their hands, as there was no modernization or extension of secondary and university teaching before the late nineteenth century. The increasing frailty of the notables' power each time that state model sought to restore its bases (in the 1830s, after 1849 and after 1871) resulted from the ongoing, accelerating collapse of the objective foundations needed for this system to be politically viable. With each crisis, urban workers' uprisings, the growing political autonomy of peasants (owing to their increasingly early awareness of universal suffrage), the decreasing social influence of landowners and the worsening ideological divisions between fractions of the notability, as well as the rise of "capacities" and of the middle classes, made restoring the former political order a more and more problematic prospect. To recreate suitable conditions, which were far better met in England, the notables' political representatives transposed, without great success, foreign traditions or artificial mechanisms of protection against social and political decline: majorats, ennoblement of grands bourgeois, electoral tweaks (including the "double vote" during the Restoration, and a law that restricted universal suffrage in 1850), the émigrés' billions law to re-establish the wealth of the nobility, an attempt to restore the Church's power, the political use of the administration, paternalism towards workers in some mining (Massif central) or textile (Nord, Alsace) regions, agronomic innovation, a form of agrarianism that purported to defend the peasant classes, the indirect control of legislative power by a high chamber or irremovable senators, etc. All these remedies to decline failed, whereas the English ruling class managed to monitor the extension of suffrage to new strata at little cost until the turn of the twentieth century.

The regional example of Franche-Comté, which Claude-Isabelle Brelot described in detail, sheds light on how the phenomena I describe very broadly here worked in practice. In that predominantly rural and conservative region, the nobles attempted an aggiornamento that is somewhat comparable to what the Prussian and English nobles did: they tried to recover land that had been taken away during the revolutionary period, farmed out to increase their land income by taking advantage of rural demographic pressure; some, albeit a minority, experimented with rational agromanagement when they farmed their own land, and even ventured into industrial investments (in mines, metalwork). Despite this acceptance of the modern world, at odds with the frequent caricatures of a nobility that refused the new century, these 
remedies to decline turned out to be insufficient. Lacking sufficient land, a large part of the petite noblesse had to resort to seeking out public posts or local elected offices to safeguard their social influence or combine sources of income to make up for their diminishing land and rent incomes. However, this introduction in the state entailed a costly investment in education (children had to be enrolled in boarding schools in the cities or in Paris), if not regional uprooting, which partly ran counter to the goal initially pursued. As Brelot put it: "In a paradox, the nobility [of FrancheComté] had to work hard to live nobly." (Brelot, Book 1 p. 409).

This example also shows that the erosion of the notables' regime and the political decline of the nobility cannot be mechanically attributed to the emergence of cities and the entry into the industrial age. In fact, while England was clearly much more advanced in the nineteenth century's movement towards urbanization and industrialization, the gentry and the aristocracy's power remained unchallenged until the late nineteenth century. The problem was actually far older than the emancipatory momentum of the people commonly assumed to be inherent in "modernity". It lay in the contradiction between this form of designation of the notables liable to reach the top of the state pyramid and the organizational principles of the new Napoleonic state, which operated from the top and the centre. As it happened, despite tentative steps, the regimes that relied on the notables and on a far more decentralized power ultimately did not venture to challenge either centralization or the deterritorialized character of the administrative elites belonging to the grands corps or the central administration. In England, on the contrary, the ruling class fought to avoid state intervention and only extended its influence in the event of a serious deficiency or when the corporations in charge of dealing with a public problem faltered, as evidenced by the protracted process of the adoption of the reform of municipal organization at a time when urban growth revealed the archaism of structures inherited from the Middle Ages. In France, governments introduced increasing numbers of appointed civil servants at all political levels, both to ensure that senior officials remained faithful to them and to retain control over the electorate using the prestige of functions - not that of names and social seniority (as in England). In the process, they contradicted the very principle of property-based devolution of power that legitimized this political model. Thus, they combined the drawbacks of their system (where lobbies and local interests weighed excessively in the balance) with those of the system they sought to replace (in which the influence of the central state at local levels resulted in political servility and clientelism). ${ }^{3}$

In centralized states like France, the reproduction of state elites remained a key question for the future of each regime. To some extent, early nineteenth century France was a pioneering nation, with its special schools, its corps and the first concours. Yet, this institutional framework was partly a smokescreen. The prestige of the Napoleonic state and the existence of these paths created aspirations to hold higher public offices within a broad circle of bourgeois and middle-class

\footnotetext{
${ }^{3}$ On the weight of civil servants in the Chamber of Deputies during the July Monarchy, see Tudesq (1967), and Girard et al. (1976), p. 14-17, and, among the conseillers généraux [departmental councellors], Tudesq (1967) and Girard et al. p. 48 (1967).
} 
individuals, whereas in practice these offices were earmarked for a small group with ties to the ruling teams. Insofar as access to elite state positions yielded multiple benefits and allowed to control power chains, step by step down to the local level, administrative competition became a crucial process (hence the brutal purges accompanying regime changes), and the resentment of those who found themselves excluded sparked major political tensions.

The hyperconcentration of university and high school students in the capital made the problem worse. It worked as an incentive for some of them, once they had graduated, to not return to their region of origin, but instead attempt to enter one of the Parisian professional markets - the main two for graduates being administration and legal professions (the latter often acting as a springboard for access to the former) (Caron 1991; Royer et al. (1982). This resulted in congestion at the base, which could only be resolved using access to the networks of protection and social and political patronage that made arbitrary picks between applicants with equivalent levels. Rejected aspirants then faced the prospect of getting back to where they had begun and starting over, even though equivalent positions were not available regionally due to centralization. They could also attempt to pursue an alternative, political strategy consisting of the accelerated accumulation of another form of social capital (such as being introduced into networks of opponents), assuming that in the short or medium term, considering the country's political instability, the existing chains of patronage would be dismantled.

As Heinrich Best showed, the political personnel in 1848 was thus largely drawn from this counter-elite of "capacities", who had been temporarily - but also, with each generation, structurally - barred from holding administrative and political power positions. Tellingly, one of the first measures taken under the Second Republic was the foundation of a school of administration to regulate access to the state's higher offices fairly Thuillier (1983). Minister of Public Instruction Hippolyte Carnot was thereby responding to the aspirations of fractions of the population who embraced reproduction through education but lacked sufficient social capital to access administrative positions and were as a result forced to fall back on low-level legal work, teaching, military careers or local civil service (Wright 1976).

In England, due to the delayed modernization of universities, neither liberal professionals (who were grouped into elitist corporations whose members were trained on the job, not in universities) nor senior civil servants (who were very few and virtually all came from the same circles as the gentry in power) could form a genuine counter-elite. Only at the tail end of the nineteenth century did such a fraction emerge, made up of Fabian intellectuals with connections to the workers' movement, who felt excluded from the establishment to such an extent that they were eager to reform the state. It was also at that time that the members of the commercial bourgeoisie, who had first conquered local power, managed to access governmental positions. 


\section{The Classic Republican Compromise: Merging with Civil Society?}

The last form of organization of the relations between elites and state is that of the "classic" Republican model that prevailed during most of the Third and Fourth Republic. It was defined by its opposition to the other two models: against centralism, against the merging of administrative and political power, and against the domination of notables. To what extent, however, did the processes of selection of state elites actually depart from previous models? Did they bring civil society closer and facilitate relations between the centre and the periphery? These three objectives had been stated in the initial Republican programmes, but the previous elites had fallen short of achieving them. Despite the opportunism of its rulers and its slow implementation of social reforms, Republican France rose up to these challenges far more than other comparable European nations did at the time. Available statistics show that deputies and ministers became socially closer to civil society, albeit with a bias in favour of liberal and intellectual professions. Political careers remained somewhat inaccessible to working-class individuals, as for a long time there were no democratic parties liable to make up for the hidden cens or "political illegitimacy". They became, however, a new channel of promotion for members of the middle class, whose most spectacular cases were used by the regime as illustrations. Although, as in the time of the notables, money remained a significant factor in the political selection system, it was no longer an insurmountable obstacle, especially when parties organized after 1900. Educational capital, which can be measured based on the numbers of deputies and ministers with higher education, did on the other hand remain a key factor. The Republic replaced Guizot's call to whoever aspired to govern France or wield some sort of social power, to "enrich" themselves with Ferry and his followers' call to "instruct" themselves.

The politicians who dominated under the Third Republic generally received secondary education, and sometimes went on to study at the law faculty. They had mostly provincial backgrounds, which made it easier for them to secure lasting political strongholds. The influence of these groups, whose members were recruited in liberal professions or in mid-level civil service in the political field and in provincial senior civil service, reflected the philosophy of this type of regime: they ensured a convenient liaison between centre and periphery and the representation of multiple interest groups.

This was a French political specificity, especially compared to Germany or England. ${ }^{4}$ In Germany, the share of liberal professions in the political personnel only increased with the Weimar Republic, even as the big organized parties offered an alternative channel of promotion (Zapf 1965; Charle 2018). In France, the seniority of their intervention and the slow evolution of society at large (with rural voting districts and mid-size towns predominating, and weak organized centrist and

\footnotetext{
${ }^{4}$ Mayeur et al. (2003), in particular my contribution pp. 45-63, and Estèbe (1982).
} 
right-wing parties) allowed the lawyers to retain the role they had fought so hard for in the 1870s until the interwar period.

This historical and functional explanation is however insufficient; global morphological data also came into play. The number of lawyers registered at the bar remained remarkably stable for a century, since the high tally of 1840 (5594) was only surpassed in 1957 (5725) despite the considerable increase in the number of aspiring lawyers. ${ }^{5}$ Thanks to all sorts of mechanisms of co-optation, discouragement or indirect selection, holders of high-level legal professions steered most graduates towards other professional markets (private sector, civil service, other liberal professions), which allowed them to maintain their scarcity over the long term and to retain control over the ethical standards promulgated by the conseils des ordres, whose member were bar elites. Over that entire period, this group of under 6000 individuals also had preferential access to a wide range of political and administrative careers: 500 to 600 seats at the Chamber, 300 at the Senate, 300 to 400 subprefectures, 90 prefectures, 3000 magistrate positions, not to mention the thousands of local mandates that served as springboards for these positions. In other words, for these individuals, who by definition were endowed with the requisite educational capital, and whose training put them in touch with the individuals who already held these positions, there was, during the Third Republic and part of the Fourth Republic, an optimal balance between the population of bar-registered lawyers (under 5000 individuals) and political and administrative career opportunities (4500 to 5000 positions).

Territorial and judicial postings were attributed at the discretion of the dominant political fraction, whose members were mainly nobles of the robe themselves. The constant exchanges of favours between lawyers who aspired to pursue political careers, deputies, ministers, prefects and magistrates - supported by their colleagues in inferior ranks: general councillors, mayors, sub-prefects, justices of the peace ensured the control of areas of sovereign state power, whereas technical or new areas, on the other hand, were entrusted mainly to members of the corps who recruited through closed competition processes. This model would endure until the Liberation.

Despite mutual borrowings, the German, British and French political models owed much to national idiosyncrasies. The relations between centre and periphery, the weight of the aristocracy and its degree of endogamy, the extent of the openness of the higher education system and the career paths it led to contributed to legitimating or thwarting the social reproduction of elites and the political regimes associated with them.

${ }^{5}$ Weisz 1983, p. 236. 


\section{References}

Agulhon, M. (2002). 1848 ou l'apprentissage de la République (1848-1851). Paris: Le Seuil, «Points».

Anceau, E. (2000). Les députés du Second Empire. Prosopographie d'une élite au XIXe siècle. Paris: Champion.

Bessel, R. (1993). Germany after the First World War. Oxford: Clarendon Press.

Bravard, A. (2013). Le Grand monde parisien 1900-1939. La persistance du modèle aristocratique. Rennes: PUR.

Brelot, C.-I. (1992). La Noblesse réinventée. Les nobles de Franche-Comté de 1814 à 1870. Besançon, 2nd vol. Paris, Annales littéraires de l'Université de Besançon, Les Belles Lettres.

Caron, J.-C. (1991). Générations romantiques 1814-1851. Les étudiants de Paris et le quartier latin. Paris: Armand Colin.

Charle, C. (1980). Les Hauts Fonctionnaires en France au XIXe siècle. Paris: Gallimard.

Charle, C. (2018). La crise politique des sociétés impériales de l'après guerre à l'avant guerre. In G. Procacci, N. Labanca, \& F. Goddi (Eds.), La guerra e lo stato (pp. 425-450).

Estèbe, J. (1982). Les ministres de la République (1871-1914). Paris: Presses de la FNSP.

Girard, L., Prost, A., \& Gossez, R. (1967). Les Conseillers généraux en 1870. Paris: PUF.

Girard, L., Serman, W., Cadet, E., \& Gossez, R. (1976). La Chambre des députés en 1837--1839. Paris: Publications de la Sorbonne.

Grange, C. (1995). Les Gens du Bottin mondain. Paris: Fayard.

Grange, C. (2016). Une élite parisienne. Les familles de la grande bourgeoisie juive (1870-1939). Paris: CNRS éditions.

Guillemin, A. (1982). Aristocrates, propriétaires et diplômés. La lutte pour le pouvoir local dans le département de la Manche 1830-1875. Actes de la recherche en sciences sociales, 42, 33-60.

Hobsbawm, E. (1996). La middle class anglaise. In J. Kocka (Ed.), Les Bourgeoisies européennes (pp. 108-109). Paris: Belin.

Kaelble, H. (1996). Bourgeoisie française et bourgeoisie allemande. In J. Kocka (Ed.), Les Bourgeoisies européennes. Paris: Belin.

Koselleck, R. (1981). Preussen zwischen Reform und Revolution, Allgemeines Landrecht, Verwaltung und soziale Bewegung von 1791-1848. Stuttgart: Ernst Klett (3rd ed. 1st ed: 1967).

Mayeur, J.-M., Chaline, J.-P., \& Corbin, A. (Eds.). (2003). Les parlementaires de la IIIe République. Paris: Publications de la Sorbonne.

Denis, M. (1977). Les Royalistes de la Mayenne et le monde moderne (XIXe-XXe siècles). Paris: Klincksieck.

Nord, P. (1995). The republican moment: Struggles for democracy in nineteenth century France. Cambridge: Harvard University Press.

Pourcher, Y. (1987). Les Maîtres de granit. Les notables de Lozère du XVIIIe siècle à nos jours. Paris: O. Orban.

Royer, J.-P., Martinage, R., \& Lecocq, P. (1982). Juges et notables au XIXe siècle. Paris: PUF.

Schubring, G. (1991). Spezialschulmodell versus Universitätsmodell. Die Institutionalisierung von Forschung. In G. Schubring (Ed.), «Einsamkeit und Freiheit » neu besichtigt. Universitätsreformen und Disziplinenbildung in Preussen als Modell für Wissenschaftspolitik im Europa des 19. Jahrhunderts (pp. 276-326). Stuttgart: Steiner Verlag.

Taine, H. (1872). Notes sur l'Angleterre. Paris: Hachette.

Thuillier, G. (1980). Bureaucratie et bureaucrates en France au XIXe siècle. Genève: Droz.

Thuillier, G. (1983). L'ENA avant l'ENA. Paris: PUF.

Tudesq, A.-J. (1967). Les Conseillers généraux au temps de Guizot. Paris: Armand Colin.

Vigreux, M. (1987). Paysans et notables du Morvan au XIXe siècle jusqu'en 1914. ChâteauChinon: Académie du Morvan.

Vincent, M.-B. (2006). Serviteurs de l'Etat, les élites administratives en Prusse de 1871 à 1933. Paris: Belin. 
Weisz, G. (1983). The emergence of modern universities in France, 1863-1914. Princeton: Princeton University Press.

Whetham, E. H. (Ed.). (1978). The agrarian history of England and Wales, vol. VIII, 1914-1939. Cambridge: Cambridge University Press.

Winter, J. (1989). Some paradoxes of the first world war. In R. Wall \& J. Winter (Eds.), The upheaval of war. Family, work and welfare in Europe 1914-1918 (pp. 9-42). Cambridge: Cambridge University Press.

Wright, V. (1976). L'École nationale d'administration de 1848-1849: un échec révélateur. Revue historique, CCLV/1, 21-42.

Zapf, W. (1965). Wandlungen der deutschen Elite. Munich: Piper.

Open Access This chapter is licensed under the terms of the Creative Commons Attribution 4.0 International License (http://creativecommons.org/licenses/by/4.0/), which permits use, sharing, adaptation, distribution and reproduction in any medium or format, as long as you give appropriate credit to the original author(s) and the source, provide a link to the Creative Commons license and indicate if changes were made.

The images or other third party material in this chapter are included in the chapter's Creative Commons license, unless indicated otherwise in a credit line to the material. If material is not included in the chapter's Creative Commons license and your intended use is not permitted by statutory regulation or exceeds the permitted use, you will need to obtain permission directly from the copyright holder.

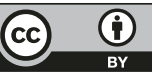

